\title{
The Changing Regional Architectures in Asia and Their Potential Implications
}

Cai Penghong

\begin{abstract}
Triggered by the ever closer regional integration and the rise of China, the geopolitical landscape of Asia has changed greatly since the end of the Cold War. Not only have a large number of new institutions for regional cooperation emerged, but China and some smaller countries are also playing an ever more active role in regional architecture building. Yet, the proliferation of various institutions indicate that the region lacks a unified or comprehensive institution, especially in the security domain. With the U.S.-led Trans-Pacific Partnership (TPP) as well as China's many strategic initiatives competing for membership, major powers are slowly taking the lead in the building of regional economic architecture, while the new security architecture in Asia is evolving around how major powers, China and the U.S. in particular, seek regional leadership by working with each other, and engage all other countries to address their common challenges. Within this context, China must have a balanced strategy between its domestic development goals and international endeavors, and speeding up its domestic reform and opening-up will be the basis of its growing leadership in future regional architecture building in Asia.
\end{abstract}

Cai Penghong is Senior Fellow at the Shanghai Institutes for International Studies, 195-15 Tianlin Road, Shanghai, China, 200233, caipenghong@siis.org.cn.

(c) 2015 World Century Publishing Corporation and Shanghai Institutes for International Studies China Quarterly of International Strategic Studies, Vol. 1, No. 4, 591-607

DOI: 10.1142/S2377740015500281 
Keywords: Regional architecture; Asian institutions; Asian order; Chinese foreign policy.

The regional architectures in Asia have been undergoing major changes over the past two decades. Despite chronic weaknesses, these architectures started their rapid evolution since the end of the Cold War, especially with the dawn of the twenty-first century. A multitude of official statements or political efforts from nearly all countries in the region have triggered a dynamic wave of regional institution-building which helped shape a new regional economic, political, and security order. It is commonly argued that the rise of China is the strongest driving force behind the power reconfiguration in Asia, which has also exerted lasting influence over the development of regional architectures. Within these contexts, this paper aims to analyze China's role in building regional architectures in Asia. First, it surveys the current regional political, trade, and security institutions; then it discusses the major causes as well as implications of the evolution of the regional architectures; finally, it provides some recommendations on how China can play a more contributory role in the building of regional architectures in Asia.

\section{Regional Architectures in Asia: an Assessment of the Current Institutions}

Originally utilized to describe buildings and other structures, the term "architecture" was introduced to international studies one to two decades ago. Generally speaking, international architectures are arranged in the form of trade, finance, politics, and security while similar arrangements in Asia are mostly focused on trade and security. ${ }^{1}$

During the Cold War era, the U.S. as a major victor of World War II remained a leading superpower as well as the economic powerhouse in the world. However, at that time due to its limited influence in the region, the U.S. was not in a position to establish an inter-governmental institution that

${ }^{1}$ Dick K. Nanto, “East Asian Regional Architecture: New Economic and Security Arrangements and U.S. Policy," CRS Report for Congress, January 4, 2008, https://www.fas. org/sgp/crs/row/RL33653.pdf. 
could serve Asia's interests. Around the end of the 1970s, led by Japan and Australia, regional cooperation and economic integration in Asia was initiated and the Asia-Pacific Economic Cooperation (APEC) was established in 1989. Thereafter, miracles of East Asian development were witnessed which could be attributed to the economic achievements of Japan, South Korea, Taiwan, Hong Kong, and Singapore. The "flying geese paradigm" was then used as a theoretical basis for interpreting the economic order in Asia. In this paradigm, the U.S. was regarded as the economic pioneer, followed by Japan and the other newly industrializing economies (NIEs). There was no fulcrum prepared for China in the regional economic architecture. In terms of security, Asia was originally not equipped with a regional institution as stipulated in the Charter of the United Nations for safeguarding collective security, while architectures with the defensive characteristic of the Cold War era did exist in Asia that were primarily bilateral, structured around the U.S. or residues of the USSR-led socialist bloc, typically the China-DPRK and China-Vietnam military alliances. After the end of the Cold War and the collapse of the socialist bloc, ASEAN was for once regarded as a fulcrum, in spite of its questionable credentials as an organization representing the whole of Asia. Today, ASEAN has developed into a comprehensive mechanism that envisions a sub-regional community, with security topics integrated into its various agendas.

There is a deficit of security institutions in Asia despite the many economic institutions created in the past two decades.

Over the past decades, some new regional institutions have sprung up in Asia, most of which are of an economic nature. It is notable that there are now over a hundred regional trade institutions in Asia, including some dialogues and forums, a large proportion of which were created against the backdrop of economic regionalization. In contrast, security-oriented institutions in Asia have been much less developed. In Northeast Asia, the former socialist bloc and especially the China-DPRK alliance no longer exist while the American-dominant security system of bilateral alliances remains fully operational. Meanwhile, a multilateral security structure composed of some newly established and rising institutions is emerging on the geopolitical horizon of Asia. These institutions have mainly been launched by sovereign nations with the aim of promoting economic and political 
development as well as serving security interests in the region. Table 1 shows the features of a variety of economic, political, and security institutions with potential influence on the rearrangement of the regional order in Asia.

First, a large number of new institutions, most of which are focused on economic cooperation, have been set up in Asia since the end of the

Table 1. Major Regional Institutions in Asia.

\begin{tabular}{|c|c|c|c|}
\hline Name & Established & Membership & Major Functions \\
\hline $\begin{array}{l}\text { Asia Development } \\
\text { Bank (ADB) }\end{array}$ & 1966 & 67 & $\begin{array}{l}\text { Its primary goal is to reduce poverty and } \\
\text { promote economic and social devel- } \\
\text { opment in Asia. }\end{array}$ \\
\hline $\begin{array}{l}\text { ASEAN Defense } \\
\text { Ministers Meeting } \\
\text { Plus (ADMM+) }\end{array}$ & 2010 & 18 & $\begin{array}{l}\text { Based on the ASEAN Defense Ministers' } \\
\text { Meeting (ADMM) established in } \\
\text { 2006, it is a security forum for de- } \\
\text { fense officials to meet biennially to } \\
\text { exchange views on regional and } \\
\text { international security issues. }\end{array}$ \\
\hline $\begin{array}{l}\text { Asian Infrastructure } \\
\text { Investment Bank } \\
\text { (AIIB) }\end{array}$ & 2015 & $\begin{array}{l}52 \\
\text { (as of } \\
\text { September } \\
30,2015)\end{array}$ & $\begin{array}{l}\text { Proposed by China in } 2013 \text { and inau- } \\
\text { gurated in Beijing in June 2015, it } \\
\text { basically aims to fund regional in- } \\
\text { frastructure development, especially } \\
\text { transportation projects. }\end{array}$ \\
\hline $\begin{array}{l}\text { Asia Pacific } \\
\text { Economic } \\
\text { Cooperation } \\
\text { Leaders Informal } \\
\text { Meeting (AELM) }\end{array}$ & 1993 & 21 & $\begin{array}{l}\text { Initiated by the U.S. and established out } \\
\text { of the APEC ministerial forum, it } \\
\text { emphasizes economic cooperation } \\
\text { among members. It cannot become a } \\
\text { security mechanism mainly because } \\
\text { some members like Taiwan and } \\
\text { Hong Kong are not sovereign states. }\end{array}$ \\
\hline $\begin{array}{l}\text { ASEAN Regional } \\
\text { Forum (ARF) }\end{array}$ & 1994 & 27 & $\begin{array}{l}\text { Proposed by ASEAN leaders, the ARF } \\
\text { was set up for preventive diplomacy } \\
\text { and to explore confidence-building } \\
\text { and conflict-resolving measures. } \\
\text { With expanding membership, it is } \\
\text { slowly shifting focus onto non-tradi- } \\
\text { tional security issues such as disaster } \\
\text { management and counter-terrorism, } \\
\text { while its original security function is } \\
\text { being taken over by the ADMM+. }\end{array}$ \\
\hline $\begin{array}{l}\text { Association of } \\
\text { Southeast Asian } \\
\text { Nations (ASEAN) }\end{array}$ & 1967 & 10 & $\begin{array}{l}\text { Expected to develop into an all-round } \\
\text { ASEAN Community by the end of } \\
\text { 2015, it aims to enhance economic } \\
\text { growth, social progress and cultural } \\
\text { development of member states, as } \\
\text { well as to promote regional peace } \\
\text { and stability. }\end{array}$ \\
\hline
\end{tabular}


Table 1. (Continued)

\begin{tabular}{|c|c|c|c|}
\hline Name & Established & Membership & Major Functions \\
\hline $\begin{array}{l}\text { Bo'ao Forum for Asia } \\
\text { (BFA) }\end{array}$ & 2001 & N/A & $\begin{array}{l}\text { Set up by China in Bo'ao, Hainan Prov- } \\
\text { ince, it is a non-official forum where } \\
\text { hundreds of world political and } \\
\text { business elites meet annually to dis- } \\
\text { cuss regional political, security and } \\
\text { economic issues. }\end{array}$ \\
\hline $\begin{array}{l}\text { Conference on Inter- } \\
\text { action and Confi- } \\
\text { dence Building } \\
\text { Measures in Asia } \\
\text { (CICA) }\end{array}$ & 1993 & 26 & $\begin{array}{l}\text { Initiated by Kazakh President Nursultan } \\
\text { Nazarbayev, CICA keeps its primary } \\
\text { purpose to promote Asian security } \\
\text { and pan-Asian confidence building. }\end{array}$ \\
\hline $\begin{array}{l}\text { East Asia Summit } \\
\text { (EAS) }\end{array}$ & 2005 & 18 & $\begin{array}{l}\text { Initiated in } 2002 \text { by ASEAN, China, } \\
\text { Japan, and South Korea } \\
\text { ("ASEAN+3"), it was established as a } \\
\text { strategic forum for national leaders } \\
\text { to discuss all salient regional issues } \\
\text { including environment, energy, } \\
\text { poverty reduction, natural disaster } \\
\text { mitigation, and finance, etc. The U.S. } \\
\text { advocates turning this summit into a } \\
\text { leading security mechanism in the } \\
\text { Asia-Pacific. }\end{array}$ \\
\hline $\begin{array}{l}\text { Shanghai Coopera- } \\
\text { tion Organization } \\
\text { (SCO) }\end{array}$ & 2001 & 6 & $\begin{array}{l}\text { Based on "the Shanghai Five" (China, } \\
\text { Russia, Kazakhstan, Kyrgyzstan, and } \\
\text { Tajikistan), the SCO was created to } \\
\text { demilitarize borders between China } \\
\text { and Russia as well as China's Central } \\
\text { Asian neighbors. Its major goal today } \\
\text { is to maintain regional peace and } \\
\text { stability, esp. to combat terrorism, } \\
\text { extremism, and separatism. Members } \\
\text { regularly conduct joint military } \\
\text { exercises, intelligence sharing pro- } \\
\text { jects, and various forms of counter- } \\
\text { insurgency cooperation. }\end{array}$ \\
\hline Six-Party Talks (SPT) & 2003 & 6 & $\begin{array}{l}\text { As an example of ad hoc multilateralism } \\
\text { in Asia, the SPT envisions the } \\
\text { creation of a security framework } \\
\text { for Northeast Asia, which has been } \\
\text { suspended since North Korea } \\
\text { announced withdrawal from the } \\
\text { negotiation in } 2009 \text {. }\end{array}$ \\
\hline
\end{tabular}

Source: Compiled by author. 
Cold War, in large part as a result of growing regionalism. A wave of marketization in Asia spurred the growth and spread of institutions throughout East and Southeast Asia. Against this background, such intergovernmental institutions as the APEC and ASEAN Plus X $(10+1,10+3$, etc.) were established. In terms of security, the American bilateral alliance framework, or the so-called "hub-and-spokes" alliance system has been confronted with a new norm referred to as collective security that was first implemented in Southeast Asia and then introduced into Northeast Asia with strong support especially from China. With the spread of new thinking in the economic and security community, Asian countries have not only benefited from new regionalism as participants but also contributed to such new institutions as the SCO and AIIB.

Second, small and middle countries or groupings have been playing a convening role. Asia is a complicated region in which different political, economic systems exist, supporting a wide range of civilizations. Big powers from external regions have special connections with, and thus continue to exert influence on, some Asian countries. During the Cold War era, the U.S. and USSR each maintained unique relations with its own bloc members in Asia. Since the end of the Cold War, ASEAN member countries started the negotiation of their sub-regional free trade agreement and then developed their connections beyond Southeast Asia. With the experiences of internal cooperation, ASEAN expanded its focal functions on economy and culture from the early period into a broader framework that covers conflict resolution, anti-piracy measures, counterterrorism, intelligencesharing, and disaster management, etc. When big powers like the U.S. and Russia tried to reengage with Southeast Asian countries, they found that ASEAN, a sub-regional institution organized by a group of small countries, was in a much better position to handle sub-regional affairs because of the establishment of some regional institutions such as the ARF and EAS. ASEAN has become a major driving force and played such a central role that no big power seems able to dominate the region anymore. In the meantime, small countries and even middle powers like South Korea have gained footholds in East Asia as well. This new phenomenon will certainly affect the building of regional architectures. The traditional regional security architecture of a bilateral nature is no longer effective and already in transition. Actually, the established superpower, namely, the U.S., has been aware that bilateral alliances can no longer meet the new geostrategic 
realities, and that it has to do more to reconstruct the regional architecture in order to make the 21st century another "American century" in the AsiaPacific. $^{2}$

Third, China is playing an ever more active role in regional architecture building in Asia. China has long kept a low profile in international and regional affairs and has been seen as a free rider. Right after the outbreak of the Asian financial crisis in 1997, China changed its attitude slightly and took some actions by proposing the ASEAN plus China $(10+1)$ cooperation and launching an FTA negotiation with ASEAN. China's initiative triggered other similar " $10+1 \mathrm{~s}$ " mechanisms such as the ASEAN-Japan, ASEAN-ROK, ASEAN-India, and even ASEAN plus Three $(10+3)$ negotiation processes, which comprise different economies and stirred up enthusiasm for Asian countries to approach each other. Since then, China have increased its involvement and tried to augment its weight in regional governance. China's role was further enhanced when it became the world's second largest economy after the 2008 international financial crisis. China's positive actions demonstrate its willingness to address the questions as to how to make more contributions to regional and global governance and how to be an accountable and responsible actor. As President $\mathrm{X}$ Jinping noted, China should strengthen overall planning and take bold initiatives. ${ }^{3}$ In a sense, the AIIB is President Xi's initiative and could be incorporated into many of these regional institutions. On security, China emphasizes the normative foundations of regional institutions, advocating common, comprehensive, cooperative, and sustainable security in Asia. China initiated the SCO and proposed to enhance the capacity and institutional building of the CICA. China maintains that such cooperation would enhance regional peace and stability, and the new norms and measures not only allow China and other Asian countries to balance the influence of any single great power, but also create opportunities for all regional countries to work together on the building of the regional community.

\footnotetext{
${ }^{2}$ Hillary Rodham Clinton, "Remarks on Regional Architecture in Asia: Principles and Priorities," Honolulu, Hawaii, January 12, 2010, http://m.state.gov/md135090.htm.

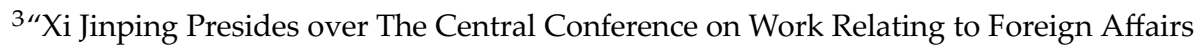
Convened in Beijing," People's Daily, November 30, 2014.
} 
Fourth, the struggle of big powers in transition has become more intense with its focus on architecture building. China's rise is believed to pose a profound challenge to the American-led regional architecture and the U.S. supremacy in the Asia-Pacific. Since the outbreak of the global financial crisis, American economic dominance has been undermined. Meanwhile, the Group of Twenty (G20), within which China commands a stronger voice, has become a premium platform for global economic governance. China's participation and its supportive role in the regional and global economic architecture have reminded the world that some existing global institutions such as the International Monetary Fund (IMF), the World Bank (WB), and the World Trade Organization (WTO) should be more open to China's perspectives and proposals. Unsurprisingly, the U.S. is making every effort to halt the momentum. From early 2010, the U.S. and its major allies in the Asia-Pacific have sped up the negotiation process of the Trans Pacific Partnership (TPP), whose major objective was widely perceived as a counterbalance against China. However, the China-sponsored AIIB reflects that China is no longer a passive participant but a creative reformer to the international financial architecture. China's action should be understood as such that new institutional arrangements will not only focus on fixing the established technical standards but also play some kind of leading role in creating new consensual norms.

In short, the creation of regional institutions over the past two decades in Asia have provided more options for China and other smaller countries to meet their needs in this critical period of power transition. Though these newly created regional institutions cannot ensure immediate harmony or eradication of disputes, least to say conflicts, in the Asia-Pacific, they are conducive to erecting a new form of regional architecture that can better meet the demand of different nations.

\section{Driving Forces behind the Asian Architecture Building}

Many have argued that the 21st century is an Asian century. However, Asia is far from ready to live up to this title. As Mr. Deng Xiaoping pointed out, 
only when China and India, the two largest nations in Asia, have become well-developed can we embrace the advent of the Asian century. The reality is that the regional order in Asia has not been fundamentally altered ever since the end of the Cold War, although economic and financial power has been greatly redistributed in the Asia-Pacific. Due to this fact, the U.S. is very likely to maintain its supremacy in the international system. The geopolitical environment in the region has been changing while the architecture building process is still underway.

In the first place, the proliferation of various forms of free trade agreements reflects that the region lacks a united or comprehensive institution. Since some five years ago, the TPP has been competing with other regional integration processes including the ASEAN Community and East Asian economic integration, among others. With the conclusion of the TPP negotiation on October 5, 2015, the big-power-dominated regional integration process has entered a new phase: the TPP, Regional Comprehensive Economic Partnership (RCEP) and/or the Free Trade Agreement of Asia Pacific (FTAAP) are all stakeholding platforms that could play vital roles in the regional integration process. In security terms, the last five or ten years have witnessed a turbulent and troubling period although the prospect of military conflicts among great powers remains unclear. Nonetheless, some inadvertent conflicts seem possible. The security environment on the Korean Peninsula has been unstable and has deteriorated in recent years. Meanwhile, maritime disputes in the East China Sea and South China Sea have become more intense. Furthermore, such non-traditional security issues as climate change, environmental

Increasing security challenges and growing need for regional economic cooperation call for joint efforts of all related nations in Asian architecture building. degradation, trans-boundary water disputes, and cyber security are all calling for better governance. Therefore, the task of building regional security architectures to promote stability in Asia is especially urgent and necessary.

Second, China's rise is a kind of stimulation to the architecture building in Asia. China's rise at this moment is attributable to its economic achievements. With its GDP having expanded 140 times from 454.5 billion RMB in 1980 to 63.6138 trillion RMB 
in 2014, ${ }^{4}$ China has overtaken Japan to be the second largest economy in the world. However, in some international and regional institutions, Western economic powers still play dominant roles, leaving China in a subordinate position. The tacit rule that the IMF and the World Bank should be headed by a European and an American citizen respectively remains unchanged. China has fewer voting shares in the IMF than France or the United Kingdom, even though China's economy is roughly four times the size of either of these EU nations. China's role is similarly circumscribed in the Asian Development Bank (ADB), which is traditionally led by a Japanese citizen. $^{5}$ The China-initiated AIIB was almost immediately embraced by interested countries, some of which were European countries, although the U.S. took a negative position toward it. The U.S. and its allies have an entrenched perception that China has invested huge resources to develop the People's Liberation Army (PLA) into a modern military force that can secure various national interests at home and abroad. The U.S. thus designed a new rebalancing strategy to hold China's growing military and economy in check. One of the many approaches by which the U.S. mobilizes its allies or new partners in Asia is to put them under the American flag to address the so-called "China threat." Though China reiterates its peaceful development approach, the U.S. still worries that its leading role will be weakened and continues efforts to enhance its influence on regional architecture building.

Third, the U.S. involvement in Asian affairs has added some variants to the regional architecture building process. Geographically speaking, the U.S. as a non-Asian country does not have any Asian identification. Yet the U.S. has some kind of connection since it claims itself to be an Asia-Pacific country. Some American scholars proposed that China and the U.S. share the responsibility to achieve better governance in the Asia-Pacific - China manages the Asian continent while the U.S. manages the Pacific Ocean. The U.S. government, however, is unwilling to share governance rights, and it

${ }^{4}$ National Bureau of Statistics of China, China Statistical Yearbook 2014 (Beijing: China Statistics Press, 2015). The data is available at http://data.stats.gov.cn/tablequery.htm? code $=$ AD02.

${ }^{5}$ Olin Wethington and Robert A. Manning," Shaping the Asia-Pacific Future" (Washington, D.C.: Atlantic Council, 2015), pp. 14-15, http://www.atlanticcouncil.org/images/publications/Shaping_AP_Future_Digital.pdf. 
intervenes in East Asian affairs under the pretext of maintaining the "freedom of navigation." A most immediate way it is doing so is by enhancing its alliance system established during the Cold War. The U.S. completed the new U.S.-Japan Defense Guidelines in April 2015 and signed the Enhanced Defense Agreement with the Philippines in 2014; it also takes every effort to establish new security partnerships with Southeast Asian countries, particularly with Vietnam, Singapore, and Indonesia.

\section{Implications of Regional Architecture Building}

The regional architectures in Asia have been built mainly in the economic and security domains and almost all the processes revolve around ASEAN and its offshoots such as the ASEAN Plus One $(10+1)$, the ARF, and the ADMM-plus. Little progress on architecture building has been made due to various reasons, and these existing processes have more or less become "talk shops." For instance, the FTAAP vision proposed at the 2004 and 2006 APEC Summits have had little progress over the past decade. The FTAAP was expected to be a legally binding mechanism, an official institution for trade negotiation, while the APEC is only a forum with its unique approach of voluntary, consensus-based decision-making processes.

With the TPP as well as China's AIIB and "Belt and Road" initiative in place, major powers are replacing ASEAN as the center of regional architecture building.
But situations are changing now. The conclusion of TPP negotiations, together with China's "Belt and Road" initiative, as well as the launch of the AIIB demonstrate that regional architecture building has entered into a new phase that will not stick to the traditional consensus-seeking ASEANcentric model. As a new regime added to the current regional economic architectures, the TPP not only symbolizes the birth of a trade agreement with much higher standards, but also underscores the role of both Japan and the U.S. as leaders of the rule-based order in the Asia-Pacific region. Historically, the U.S. and Japan have stood at the front line of the flying geese pattern in Asia and contributed a lot to the regional development which finally led to the East Asia Miracle. The region enjoys broad prosperity even without a high standard and strict trade regime like the TPP. 
At present, the roles of the U.S. and Japan are seemingly refreshed with the TPP as a revision to the economic rules set by the U.S. after World War II, while China is carrying out a new round of reform and opening up to address the economic transition. China has made full pledges to adapt itself to the changing regional architectures through several initiatives like the AIIB. The reality of the U.S., Japan, and China as important regional economies competing for dominant position in the region will certainly affect the ASEAN-centric model. The passive approach that satisfies each country without a clear roadmap to FTA agreement would be improved sooner or later.

Meanwhile, the conclusion of the TPP negotiation has implications on China-U.S. competition over the regional architecture building. According to China's proposal on the FTAAP with the Beijing Agenda announced in 2014, China intended to advance regional economic integration through the FTAAP and transform FTAAP from a vision to reality. ${ }^{6}$ Since the TPP has been defined "as a platform for regional economic integration and designed to include additional economies across the Asia-Pacific region," ${ }^{7}$ the U.S. could repel the existing FTAAP negotiations under the APEC framework, even without considering the APEC summit declarations. In the 2014 Beijing Summit Declaration, leaders of APEC member countries recognized that "APEC has a critical role to play in shaping and nurturing regional economic integration" and agreed that "APEC should make more important and meaningful contributions as an incubator to translate the Free Trade Area of the Asia-Pacific (FTAAP) from a vision to reality." These leaders also reaffirmed "their commitment to the eventual FTAAP as a major instrument to further APEC's regional economic integration agenda." ${ }^{8}$

In security terms, the proliferation of regional institutions, especially the enhancement of the U.S.-dominated institutions, has affected the ASEAN-centric status quo as well. ASEAN is a multifunctional and

${ }^{6}$ APEC, “The 22nd APEC Ecomomic Leaders' Declaration-Beijing Agenda for an Integrated, Innovative and Interconnected Asia-Pacific," November 11, 2014, http://www. apec.org/Meeting-Papers/Leaders-Declarations/2014/2014_aelm.aspx.

${ }^{7}$ Office of the United States Trade Representative, "Summary of the Trans-Pacific Partnership Agreement," https:/ustr.gov/about-us/policy-offices/press-office/press-releases/ 2015/october/summary-trans-pacific-partnership.

${ }^{8}$ APEC, “The 22nd APEC Ecomomic Leaders' Declaration-Beijing Agenda for an Integrated, Innovative and Interconnected Asia-Pacific." 
sub-regional organization equipped with a set of inter-governmental dialogues and arrangements. With its various forums, ASEAN was playing a leading role in the process of regional integration. Besides, almost all observers agree that the ADMM-plus, CICA, East Asia Summit, and the Six Party Talks have developed into multilateral systems despite their "soft" nature, yet few of them believe that these soft institutions have the capacity to fully underpin the security architecture. The ARF functions well in disaster relief and many other areas of non-traditional security, yet it can hardly move beyond confidence-building measures and carry out any operation to address border disputes within the ASEAN region. As mentioned above, the U.S.-led bilateral alliance system is a part of the legacy from the Cold War that has been upgraded to a new level. It is noteworthy that a semi-trilateral alliance has emerged among the U.S., Japan and Australia, alongside expanding U.S. partnerships with Vietnam and Malaysia. Although the U.S. does not deny ASEAN centrality and promises to support the ASEAN-centric security mechanism, there is no doubt that the U.S. will not pass on its leadership to any other regional actor, ASEAN included.

Stress has been placed on China's role in security architecture building. After the Cold War, China has made some major contributions with regard to building Asian institutions, including its new security concept proposed in the 1990s. This new security concept based on mutual trust, mutual benefit, equality, and collaboration has laid the foundation for the establishment of the Shanghai Cooperation Organization (SCO) and the improvement of bilateral relationships between China and Southeast Asian countries. In this light, President Xi Jinping put forward a "New Asian Security Concept" of common, comprehensive, cooperative, and sustainable security at the Conference on Interaction and Confidence Building Measures in Asia (CICA) on May 19, 2014. As the first external country to accept the Southeast Treaty of Amity and Cooperation (TAC), China's action has led major world powers to join this treaty. On the other hand, China's rising influence in the region has been regarded by many as a security threat. To stress China's role, some argue that an Asian NATO is imperative, but any such move would be impractical in view of the region's bitter disagreements over a common threat. Since 2010, the maritime issue in the South China Sea has become a hot topic, to the extent that the U.S. has shifted its long-term position of not taking sides in sovereignty disputes and mobilized various resources to confront China. This change demonstrates that 
the U.S. worries about the power shift and potential Chinese domination of regional architectures in Asia. The activities of the so-called "champions of new Asian order" carried out by the U.S. and Japan have generated some kind of adverse effects on China. Since the mid-1990s, China and ASEAN have adopted a normative approach of negotiation, with the final Declaration on the Conduct of Parties in the South China Sea (DOC) signed in 2002. However, the DOC has not been effectively implemented by some ASEAN countries backed with U.S. Support; the Code of Conduct of the South China Sea (COC) as stipulated in the DOC has not been finalized for the same reason. Fortunately, ASEAN countries and China have initiated discussions on the issue and, as President $\mathrm{Xi}$ mentioned, China is taking positive steps with ASEAN countries to work on the COC and is making efforts to manage the issue with the purpose of maintaining a peaceful, stable, and cooperative South China Sea. ${ }^{9}$

\section{Road to Regional Leadership: Recommendations for China}

The regional architectures in Asia have been growing quickly in the midst of booming economic institutions and a weak security system. Recently, with the TPP negotiation concluded on October 5, 2015, the regional integration process has entered into a new phase. Meanwhile, other "megaregional" FTA negotiations, such as the RCEP and the FTAAP, have become new focuses. How the RCEP and FTAAP will coordinate and coexist with the TPP is a new topic on regional architecture building.

Some believe that the Chinese tend to have a strong strategic instinct on things they will do or have already done. China, however, did not have a strategic vision to play a major role until 1991 when it was admitted to the APEC. At the end of the 1990s, China was still striving to achieve the per capita GDP level of US $\$ 1,000$, although some sharp-eyed observers predicted that China would soon become the second largest economy in the world. Now, with a GDP per capita of over US\$8000, China is at a critical point with the opportunity of taking a comprehensive FTA policy to further promote its reform and opening up.

9 “Xi Jinping Jieshou Lutoushe Caifang [Xi Jinping gives an interview to Reuters]," Xinhua News, October 18, 2015, http://news.xinhuanet.com/world/2015-10/18/c_1116859131.htm. 
How should China respond to the changing regional economic architecture?

Above all, China's mega-regional FTA strategy must be aligned with its national strategy. China's FTA strategy has been defined as an indispensable component of China's new strategy. President $X_{i}$ Jinping has pointed out that implementing the FTA strategy was a significant method to reach the goal of China's national strategy, including external strategy. ${ }^{10}$

China must have a balanced strategy of fulfilling its domestic development goals and seeking regional leadership based on amicable peripheral relations.

Next, China, as an active participant in regional architecture building, has set its goal to be a constructor of international rules. Reaching free trade agreements with other countries could give China an opportunity to promote domestic reform through making new economic rules. It is vital for China to abide by the current international rules established by the U.S. and other Western countries. Taking a gradual approach is prudent but in the 21st century China should be spurred to catch up with global standards and advance with the new era. A rising power must be a participant in and contributor to international and regional rule-making. Chinese involvement in the process of mega-FTA negotiations will test China's rule-making capabilities. Rule-based architecture building is not a zero-sum game, but a collaborative process.

Furthermore, China's neighboring countries are immediate and essential partners with whom China can develop its FTA strategy. China has not yet issued an official national FTA strategy, although President Xi Jinping has presented his new strategic thinking on forging FTA with countries at China's peripheries. Geographically, China's peripheries include the countries sharing borders with China as well as the surrounding areas in the Pacific and Indian Oceans. China has already finished negotiations or signed FTAs with South Korea, Singapore, New Zealand,

10“Xi Jinping: Jiakuai Shishi Ziyou Maoyiqu Zhanlue Jiakuai Goujian Kaifangxing Jingji Xintizhi [President Xi urges accelerated FTA strategy and Liberalized Economic Framework]," Xinhua News, December 7, 2014, http://news.xinhuanet.com/politics/2014-12/06/ c_1113546075.htm. 
Australia, and ASEAN, and Japan should be considered as the next FTA partner. With many of those FTAs and other new institutions such as the AIIB and the "Belt and Road" initiative, China has the potential to establish greater FTA networks, which will prove very helpful for China to maintain a favorable environment for its continuing rise.

Finally, although China takes an open and inclusive attitude toward the TPP, it is difficult for China to apply for TPP membership in the near future. With the Trade Promotion Act (TPA) passed in the U.S. Congress in June 2015, China should not naively believe that the Congress would say nay to the TPP. In spite of China's positive response to the conclusion of TPP negotiations, that it "hopes the TPP pact and other free trade arrangements in the region can boost each other and contribute to the Asia-Pacific's trade, investment and economic growth"11 as mentioned by Mr. Gao Hucheng, Chinese Minister of Commerce, the TPP is ultimately a key component of the American rebalancing strategy. Joining the TPP is still a far possibility for China due to potential objection of the U.S. and some other TPP members having serious disputes with China. What China can do is quicken the pace of domestic reforms and take a parallel approach: one by keeping an open and inclusive attitude to the TPP because of its high standards; the other by supporting the central role of ASEAN countries in the RCEP. China's strategic goal of integrating regional FTAs might be implemented with an emphasis on the RCEP as a spur to the nation's economic transformation. ${ }^{12}$

With its support for open regionalism, China should not reject the TPP's efforts to set up new rules. Different from the American approach, which stresses politics and security from the very beginning and then moves on to economic issues, as Ms. Susan Rice put it, "security... is the underpinning of all progress, ${ }^{13}$ China considers it comfortable to deal with Asian countries. The Chinese approach of economic development is more

11“Shangwu Buzhang Gao Hucheng Jiu Kuataipingyang Huoban Guanxi Xieding Jieshou Caifang [Minister of Commerce Gao Hucheng Gives an Interview on the TPP],"People's Daily, October 9, 2015, http://ah.people.com.cn/n/2015/1009/c358314-26703327.html.

${ }^{12} \mathrm{He}$ Ping and Shen Chen, "RCEP and China's Asia-Pacific FTA Strategy," China International Studies, No. 40 (May/June 2013), pp. 138-158.

${ }^{13}$ Susan Rice, "America's Future in Asia," Address at Georgetown on America's Future in Asia, Washington, D.C., November 20, 2013, http://www.chinausfocus.com/u-s-news/ national-security-advisor-susan-rices-address-at-georgetown-on-americas-future-in-asia/. 
effective and less controversial at home and abroad. Although China has contributed a lot to regional stability, it still needs more patience and time, awaiting the acceptance and recognition from other countries in the AsiaPacific.

In the security field, it is undoubted that there is a need to establish a regional security regime with acceptable architectures and institutions. Before the establishment of a new, mature regional order, it is worthwhile to discuss norms and principles to build an effective security cooperation mechanism in Asia. We have to admit that difficulties and challenges do exist and many traditional security problems are now reemerging. This is precisely the reason underlying research on how to establish an effective and efficient security mechanism for regional peace and stability. As mentioned above, the centrality of ASEAN seems to have been eroded because of the various forms of external interference. However, at least in the midterm, the ASEAN-centric institutions will remain pivotal for their vast inclusiveness. In the longer run, it is big powers like China and the U.S. that should play the major driving role in architecture building in the Asia-Pacific. 